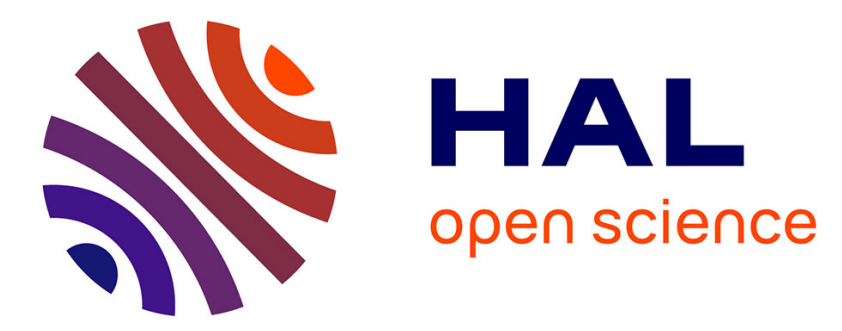

\title{
Optimization of Na-Ion Battery Systems Based on Polyanionic or Layered Positive Electrodes and Carbon Anodes
}

Romain Dugas, Bo Zhang, Patrick Rozier, Jean-marie Tarascon

\section{- To cite this version:}

Romain Dugas, Bo Zhang, Patrick Rozier, Jean-marie Tarascon. Optimization of Na-Ion Battery Systems Based on Polyanionic or Layered Positive Electrodes and Carbon Anodes. Journal of The Electrochemical Society, 2016, 163 (6), pp.A867-A874. 10.1149/2.0051605jes . hal-02319582

\section{HAL Id: hal-02319582 \\ https://hal.science/hal-02319582}

Submitted on 18 Oct 2019

HAL is a multi-disciplinary open access archive for the deposit and dissemination of scientific research documents, whether they are published or not. The documents may come from teaching and research institutions in France or abroad, or from public or private research centers.
L'archive ouverte pluridisciplinaire HAL, est destinée au dépôt et à la diffusion de documents scientifiques de niveau recherche, publiés ou non, émanant des établissements d'enseignement et de recherche français ou étrangers, des laboratoires publics ou privés. 


\section{OATAO \\ Open Archive Toulouse Archive Ouverte}

\section{Open Archive Toulouse Archive Ouverte (OATAO)}

OATAO is an open access repository that collects the work of Toulouse researchers and makes it freely available over the web where possible

This is a Publisher's version published in: http://oatao.univ-toulouse.fr/24541

Official URL: https://doi.org/10.1149/2.0051605jes

\section{To cite this version:}

Dugas, Romain and Zhang, Bo and Rozier, Patrick Optimization of Na-Ion Battery Systems Based on Polyanionic or Layered Positive Electrodes and Carbon Anodes. (2016) Journal of The Electrochemical Society, 163 (6). A867-A874. ISSN 0013-4651

Any correspondence concerning this service should be sent to the repository administrator: tech-oatao@listes-diff.inp-toulouse.fr 


\title{
Optimization of Na-Ion Battery Systems Based on Polyanionic or Layered Positive Electrodes and Carbon Anodes
}

\author{
R. Dugas, ${ }^{\text {a,b }}$ B. Zhang, ${ }^{\text {a,b }}$ P. Rozier, ${ }^{\text {b,c,d }}$ and J. M. Tarascon ${ }^{\mathrm{a}, \mathrm{b}, \mathrm{c}, \mathrm{z}}$ \\ ${ }^{a}$ Chimie du Solide-Energie, FRE 3677, Collège de France, 75231 Paris Cedex 05, France \\ ${ }^{b}$ Réseau sur le Stockage Electrochimique de l'Energie (RS2E), FR CNRS 3459, 80039 Amiens, France \\ ${ }^{c}$ ALISTORE-European Research Institute, 80039 Amiens, France \\ ${ }^{d}$ University of Toulouse III Paul Sabatier, CIRIMAT CNRS UMR 5085, 31062 Toulouse Cedex 09, France
}

\begin{abstract}
The revival of the Na-ion battery concept has prompted intense research activities toward new Na-based insertion compounds and their implementation in full $\mathrm{Na}$-ion cells. Herein, we report the optimization of full $\mathrm{Na}$-ion cells consisting of either a layered oxide $\mathrm{Na}_{x}\left(\mathrm{Fe}_{1 / 2} \mathrm{Mn}_{1 / 2}\right) \mathrm{O}_{2}$ or a polyanionic $\mathrm{Na}_{3} \mathrm{~V}_{2}\left(\mathrm{PO}_{4}\right)_{2} \mathrm{~F}_{3}$ cathode associated with a hard carbon anode. From charge/discharge curves collected via 2 or 3 -electrode measurements, the charge/discharge profiles of full cells are simulated to evaluate the maximum energy density these two systems can deliver. Similar energies of $235 \mathrm{~W} \mathrm{~h} \mathrm{~kg}^{-1}$ are found for both systems provided that a fully sodiated $\mathrm{Na}_{1}\left(\mathrm{Fe}_{1 / 2} \mathrm{Mn}_{1 / 2}\right) \mathrm{O}_{2}$ layered phase is used. Experimental cells confirm these values, and cells based on polyanionic compounds surpass the layered cathodes in terms of energy retention, average voltage and rate capabilities. By using Na sources to compensate for carbon's irreversible capacity, energy densities as high as $265 \mathrm{~W} \mathrm{~h} \mathrm{~kg}-1$ can be reached with the $\mathrm{Na}_{3+\mathrm{x}} \mathrm{V}_{2}\left(\mathrm{PO}_{4}\right)_{2} \mathrm{~F}_{3} /$ hard $\mathrm{C}$ system. Overall, such studies reveal that the gravimetric energy density advantage of layered over polyanionic compounds for Li-ion batteries vanishes by moving to Na-ion. We hope this information will be of great interest for battery manufacturers willing to enroll in the future commercialization of Na-ion batteries.

(c) The Author(s) 2016. Published by ECS. This is an open access article distributed under the terms of the Creative Commons Attribution 4.0 License (CC BY, http://creativecommons.org/licenses/by/4.0/), which permits unrestricted reuse of the work in any medium, provided the original work is properly cited. [DOI: 10.1149/2.0051605jes] All rights reserved.
\end{abstract}

Manuscript submitted December 7, 2015; revised manuscript received December 28, 2015. Published March 4, 2016.

In recent years, lithium battery technology has emerged as the major contender to power electric vehicles. However, foreseen feedstock considerations raise concerns on $\mathrm{Li}$ reserves if automotive transportation becomes fully electric and grid applications rely more on $\mathrm{Li}$ batteries in the years to come. ${ }^{1,2}$ In anticipation of such a scenario, new chemistries must be developed, and the most appealing alternative is to use sodium, $\mathrm{Na}$, instead of lithium. The development of a $\mathrm{Na}$-ion technology will be perfectly suited to mass storage applications for which cost is an issue ( $\mathrm{Na}$ is far more abundant than $\mathrm{Li}$ ) but weight is of no importance. Within this context, the revival of the Na-ion battery concept ca. 2010, which had been abandoned in the 1980's with the advent of the lithium technology, does not come as a surprise, and neither do the intense research activities generated since then.

Pleasantly such research efforts have confirmed that the current "know-how" gained from the development of Li-ion batteries can be implemented to the search for new electrodes as well as to the assembly of cells. Similar to the Li-ion technology, the two best $\mathrm{Na}$ positive electrode contenders are the Na-based layered oxides like $\mathrm{P} 2-\mathrm{Na}_{2 / 3}\left(\mathrm{Fe}_{1 / 2} \mathrm{Mn}_{1 / 2}\right) \mathrm{O}_{2}$ and the polyanionic compounds like $\mathrm{Na}_{3} \mathrm{~V}_{2}\left(\mathrm{PO}_{4}\right)_{2} \mathrm{~F}_{3}$, having capacities of $140 \mathrm{~mA} \mathrm{~h} \mathrm{~g}$ and $110 \mathrm{~mA} \mathrm{~h} \mathrm{~g}{ }^{-1}$, respectively. Negative electrodes based on alloying reactions, conversion reactions involving oxides, and also insertion reactions have been studied, with the best compromise in terms of performances and costs being hard carbons. Turning to the electrolytes, aside from the use of Na-salts $\left(\mathrm{NaPF}_{6}, \mathrm{NaTFSI}\right)$, the solvents are nearly identical, involving mixtures of cyclic carbonates (EC, PC) and non-cyclic carbonates (DMC) $)^{3}$ with the use of fluoroethylene carbonate (FEC) ${ }^{4}$ as additive like in Li-ion cells. The major difference encountered so far, and somewhat troublesome when studying $\mathrm{Na}$ half cells, lies in the physical/chemical nature of the solid electrolyte interface (SEI) layer formed and its stability upon cycling. The milder Lewis acid character of $\mathrm{Na}$ as compared to $\mathrm{Li}$, which we could first see as a positive asset, turns out to be detrimental since most of the Nabased species forming the SEI are more soluble, hence leading to a less passivating SEI. ${ }^{5}$ Fundamental mastery of SEI formation is greatly needed; the absence of such understanding can easily mislead us when testing new materials in Na half-cells. Gladly such an issue is alleviated by replacing $\mathrm{Na}$ by carbon in full Na-ion coin cells. Ponrouch et al. demonstrated the feasibility of achieving more than 125 cycles,

${ }^{\mathrm{z} E-m a i l: ~ j e a n-m a r i e . t a r a s c o n @ ~ c o l l e g e-d e-f r a n c e . f r ~}$ with less than a $10 \%$ loss in capacity, for $\mathrm{C} / \mathrm{Na}_{3} \mathrm{~V}_{2}\left(\mathrm{PO}_{4}\right)_{2} \mathrm{~F}_{3}$ cells which also demonstrated excellent rate performances. ${ }^{6}$

Research on Na-ion systems is rapidly progressing with two contender systems $\mathrm{C} / \mathrm{Na}_{3} \mathrm{~V}_{2}\left(\mathrm{PO}_{4}\right)_{2} \mathrm{~F}_{3}{ }^{7}$ and $\mathrm{C} / \mathrm{P} 2-\mathrm{Na}_{2 / 3}\left(\mathrm{Fe}_{1 / 2} \mathrm{Mn}_{1 / 2}\right) \mathrm{O}_{2}{ }^{8}$ being considered for commercialization. They both have pros and cons. The former displays excellent capacity retention but suffers from the limited positive electrode capacity $\left(110 \mathrm{~mA} \mathrm{~h} \mathrm{~g}^{-1}\right)$, a penalty that is recovered by its large redox voltage $(3.9 \mathrm{~V})$. The latter, which contains $0.67 \mathrm{Na}^{+}$per formula unit, has achieved the best performance up to now with respect to capacity $\left(140 \mathrm{~mA} \mathrm{~h} \mathrm{~g}^{-1}\right)$, but its average voltage is lower $(2.6 \mathrm{~V})$ and it cycles less efficiently. Moreover, both technologies suffer from $25 \%$ irreversibility of the carbon negative electrode during cycling.

At this stage the questions are twofold: how can we improve performances of Na-ion cells beyond today's limits? Which system is the most competitive performance-wise? Rather than pursuing the search for new high capacity sodium cathodes, we decided to focus on getting a better understanding of the leading Na-ion systems to improve their performances, namely energy densities. Here we detail the electrochemical performance of such C-based Na-ion systems using either 3 or 2 electrode cells, as a function of various parameters: the ratio of positive and negative electrode masses, the charge and discharge cutoff voltages, and the current rate. The first part of this paper deals with the half-cell testing of each electrode, with emphasis on monitoring their irreversible and reversible capacities and their dependence upon electrolyte additives and various cutoff voltages. The second part combines the assembling/testing of full Na-ion cells, both Swagelok and coin cells, together with their basic numerical simulation obtained by combining half-cell profiles. We applied this simulation approach, capable of predicting the full cell voltage, to demonstrate the need for using sodium "reservoirs" to compensate for the full cell irreversible capacity so as to achieve optimum performances with the polyanionic compound. We experimentally confirmed such simulations and could achieve energy densities (taking solely into account the amount of positive and negative electrodes) as high as $270 \mathrm{~W} \mathrm{~h} \mathrm{~kg}-1$ for $\mathrm{C} / \mathrm{Na}_{3} \mathrm{~V}_{2}\left(\mathrm{PO}_{4}\right)_{2} \mathrm{~F}_{3}$ as compared to $234 \mathrm{~W} \mathrm{~h} \mathrm{~kg}^{-1}$ for $\mathrm{C} / \mathrm{P}^{\prime} 2-\mathrm{Na}_{1}\left(\mathrm{Fe}_{1 / 2} \mathrm{Mn}_{1 / 2}\right) \mathrm{O}_{2}$ cells.

\section{Experimental}

One $\mathrm{cm}^{2}$ electrodes were obtained by punching disks out of $\mathrm{Na}_{3} \mathrm{~V}_{2}\left(\mathrm{PO}_{4}\right)_{2} \mathrm{~F}_{3}$ and hard $\mathrm{C}$ tapes laminated on $\mathrm{Al}$ current 
collectors. The carbon electrodes used for all the tests reported herein have an active material loading of 5 to $5.20 \mathrm{mg} \mathrm{cm}^{-2}$ while the active material loading of $\mathrm{Na}_{3} \mathrm{~V}_{2}\left(\mathrm{PO}_{4}\right)_{2} \mathrm{~F}_{3}$ electrodes was varied between 5.2 and $12.4 \mathrm{mg} \mathrm{cm}^{-2}$. Such electrodes were dried at $80^{\circ} \mathrm{C}$ under vacuum for $24 \mathrm{~h}$ in a Büchi oven prior to be stored and further handled in glove box (MBraun MB200B). For more specific tests, $\mathrm{Na}_{3+x} \mathrm{~V}_{2}\left(\mathrm{PO}_{4}\right)_{2} \mathrm{~F}_{3}$ and $\mathrm{Na}_{1}\left(\mathrm{Fe}_{1 / 2} \mathrm{Mn}_{1 / 2}\right) \mathrm{O}_{2}$ powders were prepared by ball milling with sodium and Super $\mathrm{P}$ carbon of $\mathrm{Na}_{3} \mathrm{~V}_{2}\left(\mathrm{PO}_{4}\right)_{2} \mathrm{~F}_{3}$ and $\mathrm{Na}_{2 / 3}\left(\mathrm{Fe}_{1 / 2} \mathrm{Mn}_{1 / 2}\right) \mathrm{O}_{2}$, respectively, following a procedure reported elsewhere. ${ }^{9}$ Since they are air-sensitive, these active materials were used directly as powders in electrochemical cells.

Electrolytes were prepared by adding $\mathrm{NaPF}_{6}$ (Stella Chemifa) to a 1:1 by weight commercial (UBE) mixture of ethylene carbonate and dimethyl carbonate so as to obtain a 1 molar solution. The water content, measured by Karl-Fisher titration (Metrohm 899 coulometer), was lower than $20 \mathrm{ppm}$. Occasionally, $1 \%$ in mass of fluoroethylene carbonate ( $98 \%$, Alfa) was incorporated when needed.

Three electrodes cells were assembled using a T Swagelok connector as cell body with the reference electrode, located in the middle of the cell stack, consisting of a plunger having on its end a $0.2 \mathrm{~mm}$ machined tip on which $\mathrm{Na}$ was spread. If not specified, full Na-ion electrochemical tests were done using CR2032 coin cells. For these cells, $12.7 \mathrm{~mm}$ diameter electrodes, 1 layer glass fibre separator (Whatman GF/D, $675 \mu \mathrm{m}$ ) and $150 \mu \mathrm{L}$ electrolyte were employed, while for three-electrode cells we used 3 layers glass fibre separator and $450 \mu \mathrm{L}$ electrolyte.

All cells were galvanostatically cycled at room temperature on VMP3 or MPG2 multi-channel potentiostats (BioLogic), indifferently. Cycle rates are given using the convention $\mathrm{C} \Leftrightarrow 1 \mathrm{~h}$ for a theoretical full charge ( 2 moles of $\mathrm{Na}$ per mole of $\mathrm{Na}_{3} \mathrm{~V}_{2}\left(\mathrm{PO}_{4}\right)_{2} \mathrm{~F}_{3}, 1$ mole of $\mathrm{Na}$ per mole of $\mathrm{Na}_{x}\left(\mathrm{Fe}_{1 / 2} \mathrm{Mn}_{1 / 2}\right) \mathrm{O}_{2}$ and 1 mole of $\mathrm{Na}$ for 6 moles of hard $\mathrm{C}$ ). In the case of full cells with hard $\mathrm{C}$ anodes, the rates were based on the amount of cathode material. Lastly, the power rate measurements were done by collecting signature curves ${ }^{10}$ as follows. The cells were first cycled four times and the signature curves taken by gradually decreasing the current rate from $5 \mathrm{C}$ to $\mathrm{C} / 50$ with relaxation until $|\mathrm{dV}| / \mathrm{dt}<6 \mathrm{mV} \mathrm{h}^{-1}$ before each rate change. Worth mentioning is that we solely report data that has been duplicated at least twice.

\section{Results and Discussion}

Testing cell components via 3-electrode measurements.-Firstly, the active materials were tested in 3-electrode cells using $\mathrm{Na}$ as counter and reference electrodes to eliminate the contribution of the sodium counter electrode ${ }^{11,12}$ and hence to provide a reliable electrochemical platform for reliably building full Na-ion cells afterwards. In parallel, such a 3-electrode set-up will be used to check the effect of electrolyte additives such as fluoroethylene carbonate (FEC).

Figure 1a shows the first cycle of a 3-electrode $\mathrm{Na}_{3} \mathrm{~V}_{2}\left(\mathrm{PO}_{4}\right)_{2} \mathrm{~F}_{3}$ (NVPF)/Na/Na cell cycled at $\mathrm{C} / 10$ from 3 to $4.3 \mathrm{~V}$ and bearing a free or FEC-based electrolyte. Cells having FEC shows greater reversible capacities $\left(110 \mathrm{~mA} \mathrm{~h} \mathrm{~g}^{-1}\right.$ vs $\left.104 \mathrm{~mA} \mathrm{~h} \mathrm{~g}^{-1}\right)$ and irreversible capacities 3 times lower ( $4 \%$ instead of $12 \%$ ). The corresponding derivative curves shown in Fig. $1 \mathrm{~b}$ are alike with however a larger polarization $(15 \mathrm{mV})$ between the charge and discharge profiles in presence of FEC, suggesting a slightly slower electrode kinetics. This is the price to pay when using FEC to achieve the optimum irreversible capacity.
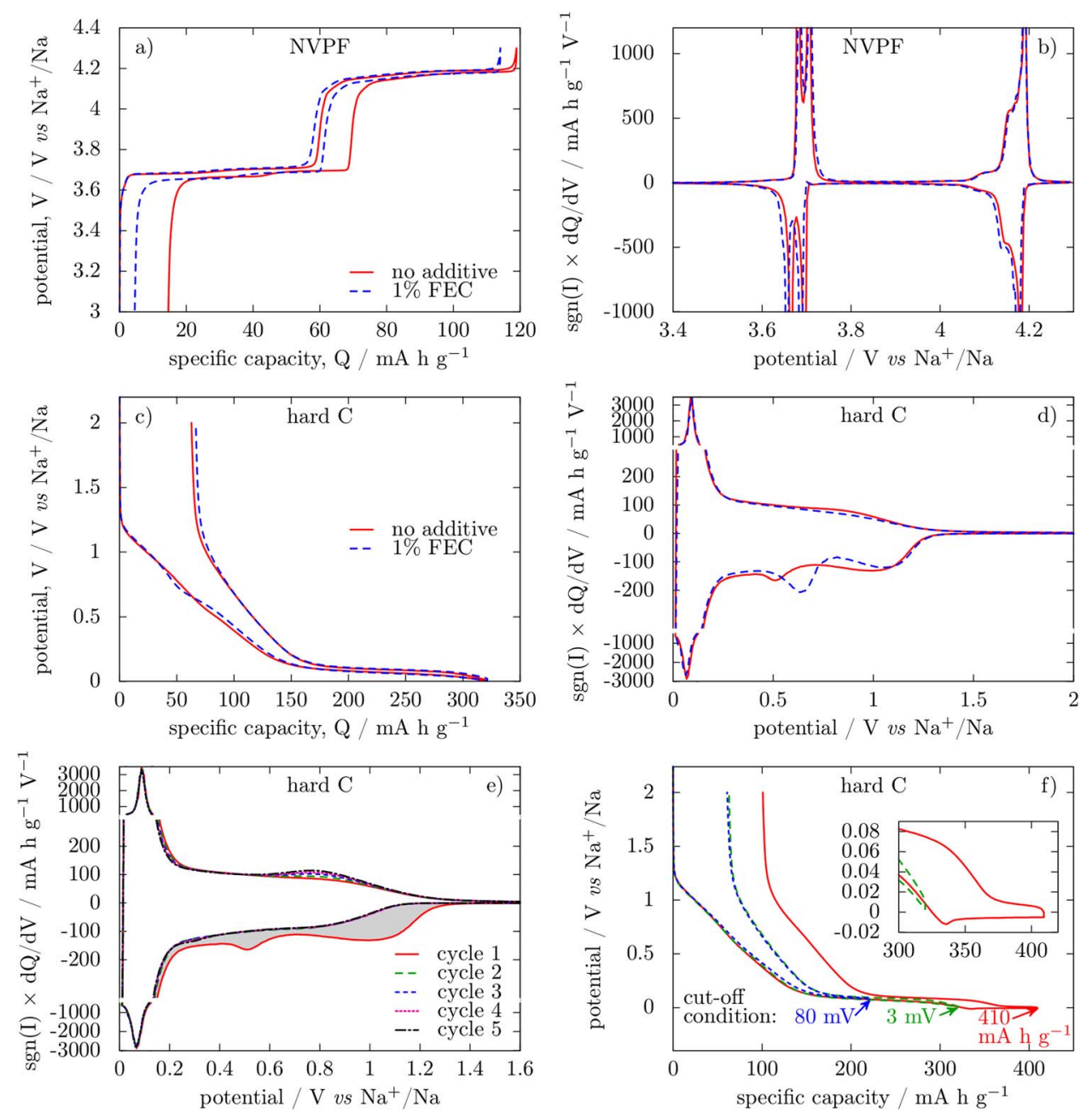

Figure 1. Performance of the active materials obtained at $\mathrm{C} / 10$ in 3-electrode cells with $\mathrm{EC}_{50} \mathrm{DMC}_{50}-1 \mathrm{M} \mathrm{NaPF}_{6}$ as electrolyte and $\mathrm{Na}$ as counter and reference electrodes for NVPF (a and b) and hard C ( $c$ to f). The 1st cycles of NVPF obtained with and without FEC additive are plotted in a) for NVPF and in c) for hard $\mathrm{C}$; the derivatives of the curves in a) and c) are shown in b) and d), respectively; the evolution of $\mathrm{dQ} / \mathrm{dV}$ for the first 5 cycles of hard $\mathrm{C}$ without additive are shown in e); and in f) is reported the first cycle of hard $\mathrm{C}$ with low cutoff at $80 \mathrm{mV}, 3 \mathrm{mV}$ or after $410 \mathrm{~mA} \mathrm{~h} \mathrm{~g}^{-1}$. 
Equally, the carbon electrode was tested by assembling $\mathrm{C} / \mathrm{Na} / \mathrm{Na}$ cells with or without FEC as additive that were cycled between 2 and $0.003 \mathrm{~V}$ at $\mathrm{C} / 10$. Whether there is presence of FEC or not, they show similar capacities with a reversible one of $\sim 257 \pm 5 \mathrm{~mA} \mathrm{~h} \mathrm{~g}^{-1}$ and an irreversible one of $\sim 62.8 \pm 1.2 \mathrm{~mA} \mathrm{~h} \mathrm{~g}^{-1}$ which reaches $73 \mathrm{~mA} \mathrm{~h} \mathrm{~g}^{-1}$ in presence of FEC. Moreover, there is a slight difference in the discharge voltage profile which shows the presence of a pseudo-plateau at $0.6 \mathrm{~V}$ for the FEC-based cell which can be nicely visualized in the derivative curves (Fig. 1d) with the appearance of a well pronounced peak centered at $0.7 \mathrm{~V}$. The oxidation derivative curves are much alike with however a weak and broad peak centered at $\sim 0.8 \mathrm{~V}$ for the FEC-free cell which we found to increase in amplitude upon cycling (Fig. 1e) to reach $6.6 \mathrm{~mA} \mathrm{~h} \mathrm{~g}^{-1}$ after 5 cycles. This contrasts with the reduction derivative curves which show the appearance of two peaks associated to the formation of the SEI during the first cycle that disappear upon subsequent cycling. This indicates that once the SEI is formed at the carbon electrode during the first cycle it remains stable afterwards through cycling, hence explaining the constancy of the observed reversible capacity shown by the cell. Integrating the SEI peaks from 0.8 to $1.5 \mathrm{~V}$ (the shaded area in Fig. 1e) leads to a capacity of $60 \mathrm{~mA} \mathrm{~h} \mathrm{~g}{ }^{-1}$, in good accordance with the $62.8 \mathrm{~mA} \mathrm{~h} \mathrm{~g}^{-1}$ irreversible capacity of this electrode. It is worth mentioning that this irreversible capacity (Fig. 1f) is independent of whether we use a discharge cutoff voltage of $80 \mathrm{mV}$ or $3 \mathrm{mV}$ which will turn later into an advantage for cell simulation.

Lastly, to explore the plating region, another cell (red curve Fig. 1f) was discharged for $11 \mathrm{~h}$ at the same rate $(\mathrm{C} / 10)$ without any potential limitation. For a capacity greater than $335 \pm 6 \mathrm{~mA} \mathrm{~h} \mathrm{~g}^{-1}$ there is appearance of an overpotential spike (5 to $10 \mathrm{mV}$ ) prior to the appearance of a plateau at $-5 \mathrm{mV}$ vs $\mathrm{Na}^{+} / \mathrm{Na}$, which is indicative of Na plating as confirmed by insitu XRD measurements. ${ }^{13}$ Note the poor reversibility of the plating process that we estimated at $55 \%$ together with the modification of the oxidation curve once plating has occurred, both indicating that reaching $\mathrm{Na}$ plating is detrimental for the cell performance.

Overall these tests enable us to define the reversible-irreversible capacities of our NVPF and $\mathrm{C}$ electrodes which are $110 \mathrm{~mA} \mathrm{~h} \mathrm{~g}{ }^{-1}$ $-5 \mathrm{~mA} \mathrm{~h} \mathrm{~g}^{-1}$ and $268 \mathrm{~mA} \mathrm{~h} \mathrm{~g}^{-1}-62 \mathrm{~mA} \mathrm{~h} \mathrm{~g}^{-1}$, respectively. Moreover, they indicate that FEC has a positive effect capacity-wise for NVPFbased cells while it has a negative effect for C-based cells. Such a difference most likely results from the suppression of redox shuttle species ${ }^{14}$ existing with NVPF which modify the nature and amount of SEI forming at the sodium electrode. Whatever the exact reasons for such a difference, which are beyond the scope of this paper, we have decided from now on not to use FEC when full Na-ion cells will be assembled.

Figure 2 reports the first cycle of $\mathrm{P}^{\prime} 2-\mathrm{Na}_{1}\left(\mathrm{Fe}_{1 / 2} \mathrm{Mn}_{1 / 2}\right) \mathrm{O}_{2}$ $\left(\mathrm{P}^{\prime} 2-\mathrm{NFM}\right) / \mathrm{Na} / \mathrm{Na}$ cells in presence of an electrolyte containing $1 \%$ FEC, cycled at $\mathrm{C} / 20$ rather than $\mathrm{C} / 10$ for NVPF-based cells because of the lower rate capability we experimented for such electrodes. We obtained a voltage-composition curve similar to what has been reported in the literature ${ }^{8}$ with a reversible capacity of $178 \mathrm{~mA} \mathrm{~h} \mathrm{~g}^{-1}$ and an irreversible capacity of $10 \mathrm{~mA} \mathrm{~h} \mathrm{~g}^{-1}$. From the average discharge voltage of $2.7 \mathrm{~V}$, as compared to $3.6 \mathrm{~V}$ for NVPF, we can deduce an energy density of $476 \mathrm{~W} \mathrm{~h} \mathrm{~kg}^{-1}$ for such an electrode.

Assembling 3-electrodes full Na-ion cells.-Three electrodes NVPF / hard C and P2-NFM / hard C full cells were assembled using the same setup as before with positive to negative electrode mass ratios $\left(\mathrm{R}_{\mathrm{P} / \mathrm{N}}\right)$ of 2.5 and 2.6 for the NVPF and P2-NFM-based cells, respectively. Note that for using the full capacity of the NVPF / hard C and NFM / hard C full cells, we were obliged to cycle the $\mathrm{NVPF} /$ hard C cells between 2 and $4.3 \mathrm{~V}$ and NFM / hard C between 0 and $4.3 \mathrm{~V}$. Such a low voltage requirement for the layered-based $\mathrm{Na}$-ion cells highlights one of their weaknesses. From the voltageprofile variation of the NVPF and $\mathrm{C}$ electrodes we can deduce that the carbon negative electrode irreversibility is limiting the system, since the carbon is fully desodiated while NVPF is far from being

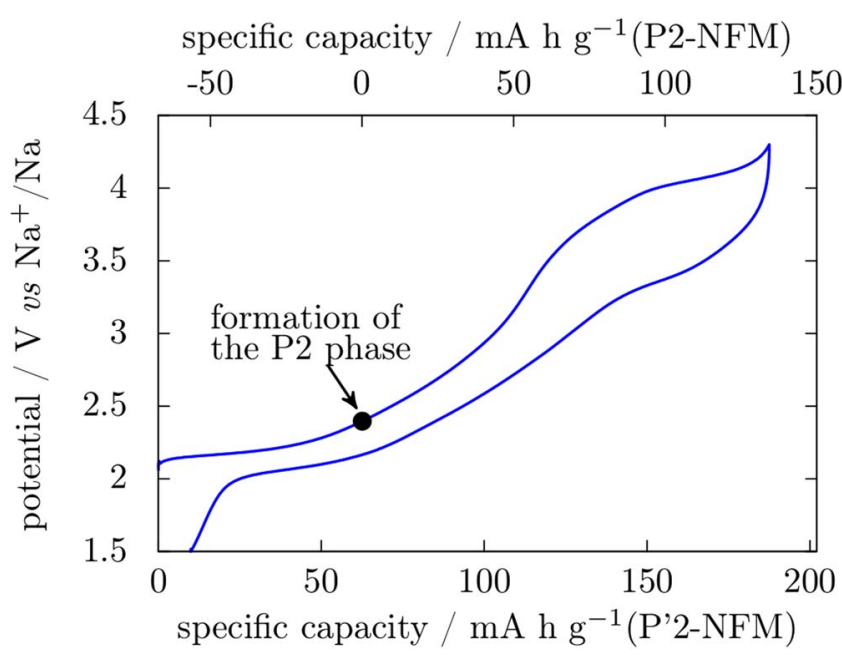

Figure 2. First cycle of $\mathrm{P}^{\prime} 2-\mathrm{Na}_{1}\left(\mathrm{Fe}_{1 / 2} \mathrm{Mn}_{1 / 2}\right) \mathrm{O}_{2}$ in $\mathrm{EC}_{50} \mathrm{DMC}_{50}-1 \mathrm{M} \mathrm{NaPF}_{6}$ and $1 \%$ FEC in mass, at $\mathrm{C} / 20 \mathrm{vs} \mathrm{Na}^{+} / \mathrm{Na}$ in 3 -electrode configuration.

fully sodiated, hence the need for better adjusting $\mathrm{R}_{\mathrm{P} / \mathrm{N}}$ or designing a Na reservoir. When P2-NFM is used as cathode material, (Figure $3 \mathrm{c}$ ), the first charge at $\mathrm{C} / 10$ is finished in $4 \mathrm{~h}$ because the starting cathode compound is not fully sodiated. Like for NVPF, the discharge is limited to the amount of $\mathrm{Na}^{+}$that can be extracted back from the anode, which corresponds to only $66 \mathrm{~mA} \mathrm{~h} \mathrm{~g}^{-1}(\mathrm{P} 2-\mathrm{NFM})$. From such measurements, it becomes obviously apparent that both systems need to be electrochemically optimized, hence our ensuing efforts ranging from a simulation of the full cells charge and discharge profiles for
NVPF - hard C
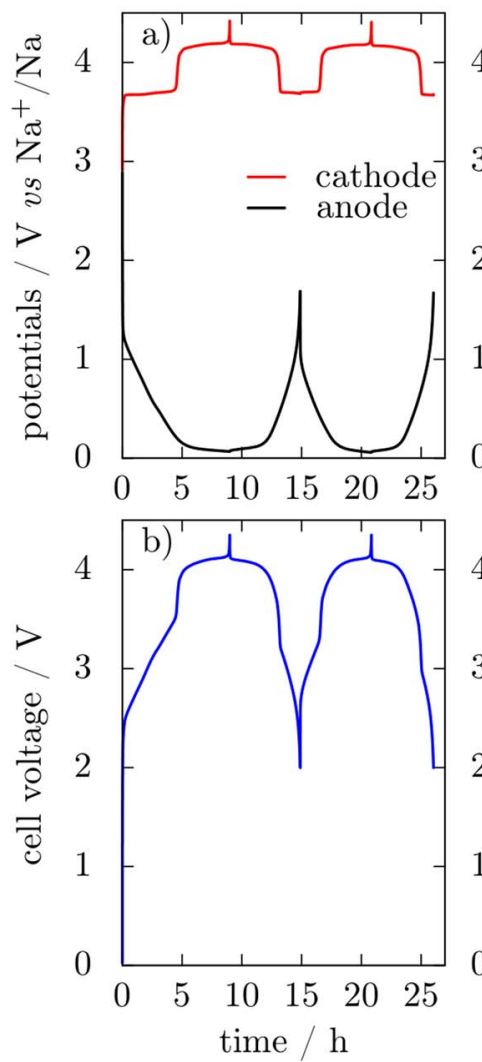

P2-NFM - hard C
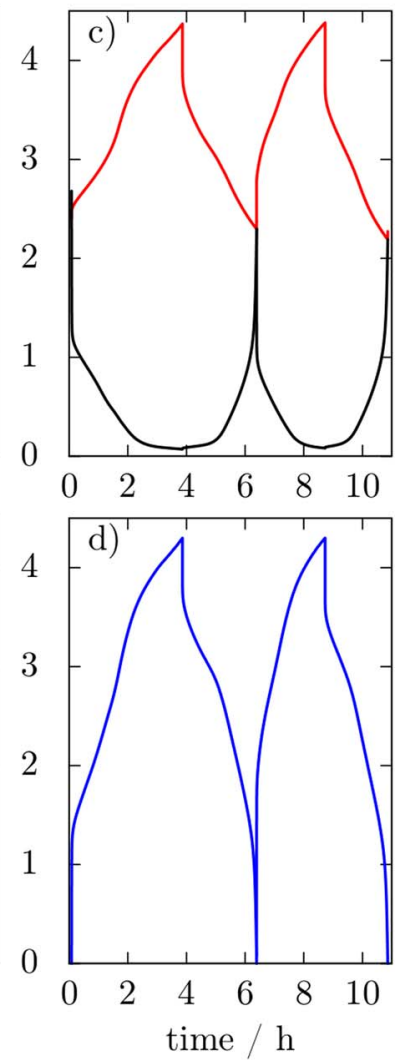

Figure 3. First 2 cycles of NVPF / hard C (a and b) and P2-NFM / hard C (c and d) full cells at C/10 in three electrode setup. In (a) and (c): potential of the electrodes measured vs the reference; in (b) and (d): voltage of the full cells. 

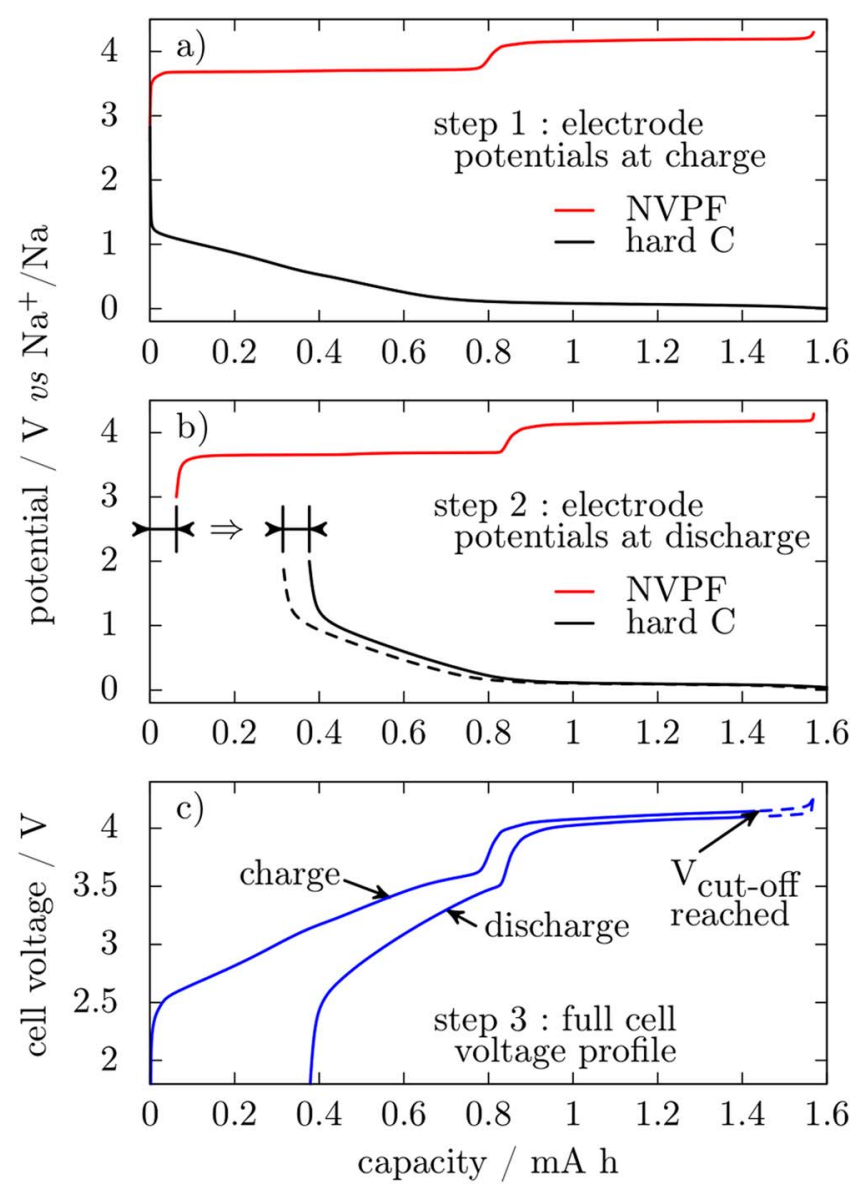

Figure 4. Procedure employed to simulate the first cycle of full $\mathrm{Na}$-ion cells, taking as an example a $5 \mathrm{mg}$ hard $\mathrm{C}$ anode, an $\mathrm{R}_{\mathrm{P} / \mathrm{N}}$ of 2.75 and $4.15 \mathrm{~V}$ cutoff voltage. At charge (a), the experimental profiles of NVPF and hard C vs $\mathrm{Na}^{+} / \mathrm{Na}$ are directly used; at discharge (b) the cathode's irreversible capacity is added to that of the anode while the cathode discharge curve is unchanged; in c) the full cell voltage profile is obtained by subtracting the anode's potential curves to the cathode's curves.

identifying the best balancings and operating voltages conditions to their implementation into practical full Na-ion cells.

NVPF / hard C coin cells.-We now describe our basic numerical simulation approach to predict the best full cell operating conditions from the previously established three-electrode measurements and describe its robustness by confronting our simulations with real data obtained by assembling FEC-free full $\mathrm{Na}$-ion coin cells having different $\mathrm{R}_{\mathrm{P} / \mathrm{N}}$ ratios and voltage scan ranges.

Our simulation proceeds as follows. First from the experimental curves obtained via 3-electrode measurements we can generate for specific $R_{\mathrm{P} / \mathrm{N}}$ ratios the voltage profile of the positive and negative electrodes as a function of charge capacity. Then, by taking advantage of the constant irreversibility of the two electrodes within their domain of practical uses as experimentally determined, we access the full cell irreversibility $C_{\text {irr }}$ by a linear combination of the two electrodes masses that we implemented to the negative electrodes because the cells discharges are carbon limited. Last, the full cell voltage profile is generated by plotting $\mathrm{V}_{\text {cell }}=\mathrm{V}_{\text {cathode }}-\mathrm{V}_{\text {anode }}$. Such a procedure is exemplified in Figure 4 which describes the various steps involved for establishing the voltage profile of a cell having $5 \mathrm{mg}$ hard $\mathrm{C}$ anode and a 2.75 times heavier NVPF cathode for which we limit the cell charge cutoff voltage to $4.15 \mathrm{~V}$. Such a simplistic modeling approach can here be applied because of the constancy of the SEI formation over a wide potential range.

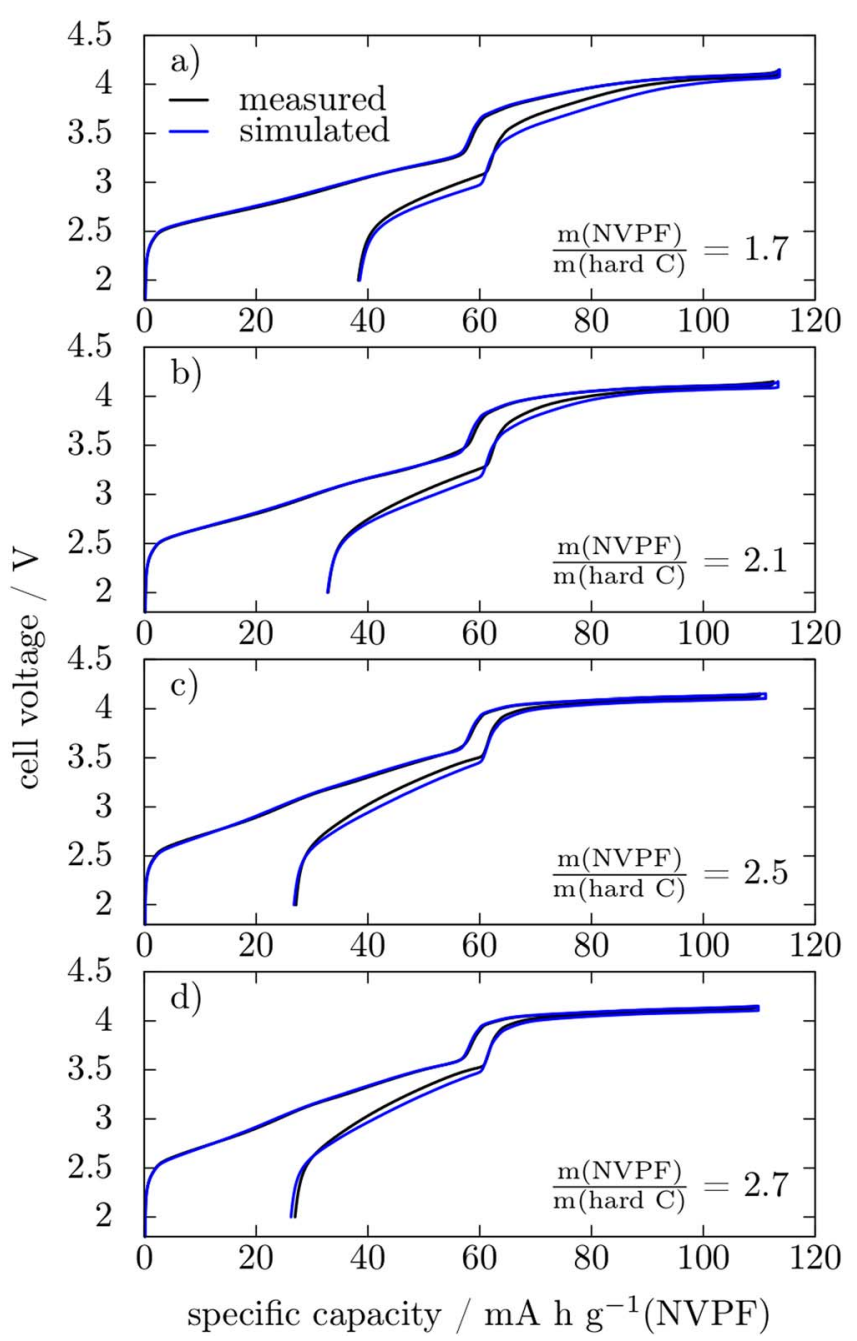

Figure 5. Experimental and simulated first cycles of full cells with $\mathrm{m}(\mathrm{NVPF}) / \mathrm{m}($ hard C) ratios of 1.7 (a), 2.1 (b), 2.5 (c) and 2.7 (d) and cutoff at $4.15 \mathrm{~V}$.

The profiles obtained with this procedure are compared to experimental profiles in Figure 5 for NVPF-based Na-ion cells having $\mathrm{R}_{\mathrm{P} / \mathrm{N}}$ of $1.7,2.1,2.5$ and 2.7 and a limiting charge cutoff voltage of $4.15 \mathrm{~V}$. In all cases, the simulated and experimental charging curves superimposed. Such a simulation does not work so equally well for the discharge curves since the experimental curves slightly deviate from the experimental ones, namely over the steepest region of the curves, with the difference being more pronounced for the lowest $R_{P / N}$. values. Such an observed deviation suggests that the carbon electrode behaves slightly differently when using either 3-electrodes or coin cells hardware for testing. Whatever, since the average discharge voltages differ by less than $2 \%$, we should note that the energies obtained by integrating the simulated curves remain nearly similar (discrepancies of $\pm 1 \%$ ). Further exploiting such a simulation, we could generate the continuous variation of the discharge energy as a function of $R_{P / N}$ ranging from 1 to 3.5 for NVPF / C cells cycled till various charging cutoff voltages $\left(\mathrm{C}_{\mathrm{cv}}\right)$ of $4.15,4.2$ and $4.3 \mathrm{~V}$. Figure 6 shows the results of this simulation, with the discharge energy reported to the total mass of carbon plus NVPF. They indicate that the NVPF / C system can offer maximum energies as high as of 219 and $237 \mathrm{~W} \mathrm{~h} \mathrm{~kg}^{-1}$ for cells having $\mathrm{R}_{\mathrm{P} / \mathrm{N}}$ of 2.57 and 2.83 and cycled to 4.15 and $4.2 \mathrm{~V}$, respectively. For better conveying the importance of cell balancing, we generated two cells having the same energy densities and charged to $4.15 \mathrm{~V}$, but having $\mathrm{R}_{\mathrm{P} / \mathrm{N}}$ on each side of the 2.57/optimal value. The cell with low $R_{P / N}$ is cathode limited (Fig. 6 left inset) while 


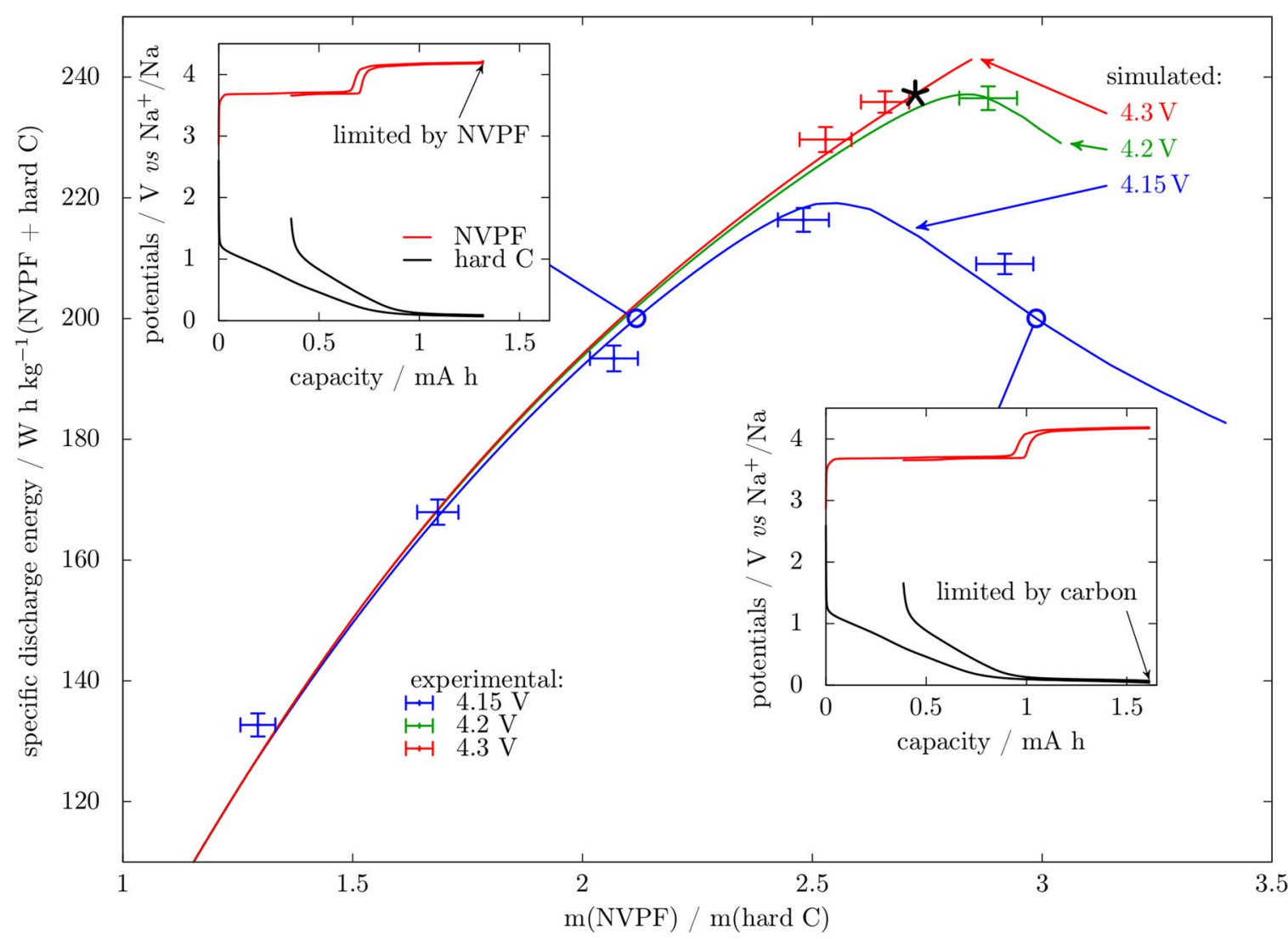

Figure 6. Simulated (lines) and experimental (points) energy density of NVPF / hard C cells for cutoff voltages of 4.15, 4.2 and 4.3 V. Insets show the working potential windows of anode and cathode for cells with $\mathrm{m}(\mathrm{NVPF}) / \mathrm{m}($ hard $\mathrm{C})=2.1$ and 3.0 and cell cutoff at $4.15 \mathrm{~V}$.

the one with high $\mathrm{R}_{\mathrm{P} / \mathrm{N}}$ is anode limited (Fig. 6 right inset), with the inherent risk of Na plating and hence safety issues. Further pursuing on this safety issue note that the curves obtained for $\mathrm{C}_{\mathrm{cv}}$ of 4.2 and $4.3 \mathrm{~V}$ are limited to $\mathrm{R}_{\mathrm{P} / \mathrm{N}}$ ratios of 3.0 and 2.85 , respectively, values above which sodium plating occurs. We confront this simulated data to experiments by assembling full Na-ion cells using various $\mathrm{R}_{\mathrm{P} / \mathrm{N}}$ that were charged to various cutoff voltages. The measured energy densities are reported as data points in Figure 6. A very good agreement between simulation and experiments is observed, further confirming the robustness of the simulation. For practical aspects note that the system maximum energy density of $237 \mathrm{~W} \mathrm{~h} \mathrm{~kg}^{-1}$ (green data point) can also be achieved (red data point + star) by using a lower $\mathrm{R}_{\mathrm{P} / \mathrm{N}}$ but a greater cutoff ( $4.3 \mathrm{~V}$ instead of $4.2 \mathrm{~V}$ ), provided we do not enhance electrolyte decomposition at such higher voltages.

At this stage, both simulations and experiments reveal that the performance of NVPF / C Na-ion cells is mainly penalized by the large irreversibility (20\%) of the C negative electrode associated to the formation of the SEI interface which consumes $\mathrm{Na}^{+}$ions. Possible strategies to combat this issues consist, as we previously reported, in using Na-rich based insertion compounds $\left(\mathrm{Na}_{3} \mathrm{P}\right.$, or $\left.\mathrm{Na}_{3+\mathrm{x}} \mathrm{V}_{2}\left(\mathrm{PO}_{4}\right)_{2} \mathrm{~F}_{3}\right)$ that act as $\mathrm{Na}$ reservoir to compensate for the irreversible capacity of the full cells. Armed with our simulation approach we next try to implement it to the optimization of NVPF / C Na-ion systems containing $\mathrm{Na}$ additives.

We here use as starting point of these simulations the configuration that is represented by a star in Fig. 6 and assume that the additive does not bring extra irreversible capacity to the cell. More specifically, as exemplified in Figure 7, the mass of hard $\mathrm{C}$ and first charge capacity are kept constant to $5 \mathrm{mg}$ and $1.55 \mathrm{~mA} \mathrm{~h}$, respectively, while the mass of NVPF is adapted to the mass of additive so that the sum of their capacities at first charge matches the $1.55 \mathrm{~mA} \mathrm{~h}$. Then, to simulate the discharge curve of such cells, the curve of NVPF is simply shifted toward higher capacities by a value corresponding to the capacity provided by the additive while the curve of hard $\mathrm{C}$ remains unchanged. The latter is then subtracted to the shifted NVPF curve as previously (Fig. 7a).

The discharge profiles obtained by this procedure are plotted in Figure $7 \mathrm{~b}$, as a function of the mass of NVPF in the cell for additive capacities of $0,0.14,0.30$ and $0.46 \mathrm{~mA} \mathrm{~h}$ which are calculated to compensate for $0,0.5,1$ and 1.5 times the irreversible capacity, $\mathrm{C}_{\mathrm{irr}}$, of hard $\mathrm{C}$ and NVPF in the cell. The full electrode capacity is therefore achieved for $\mathrm{Na}_{\text {reservoir }}$ capacity $=0.3 \mathrm{~mA} \mathrm{~h}$, with the main gain being observed at the end of the discharge.

To get the maximum energy of the system, sodium should be used as a reservoir additive since it has the highest capacity. This can be achieved by using $\mathrm{Na}_{3+x} \mathrm{~V}_{2}\left(\mathrm{PO}_{4}\right)_{2} \mathrm{~F}_{3}\left(\mathrm{Na}_{3+x} \mathrm{VPF}\right)$ as cathode material, which was prepared by ball milling of NVPF with metallic Na. ${ }^{9}$ Figure $7 \mathrm{c}$ reports the first cycle of such a $\mathrm{Na}_{3+x} \mathrm{VPF} /$ hard $\mathrm{C}$ cell. Compared to the profiles in Figure 5, the first charge of this cell displays a significant capacity below $2.5 \mathrm{~V}$ and two extra slope changes at 2.5 and $3 \mathrm{~V}$. These are the signature of the extraction of the $x$ extra $\mathrm{Na}$ from $\mathrm{Na}_{3+x} \mathrm{VPF}$. At discharge, the curve is in good accordance with the simulated one for $\mathrm{Na}_{\text {reservoir }}=\mathrm{C}_{\text {irr }}$ in Figure $7 \mathrm{~b}$. To help identify the features of the cathode, the discharge curve of $\mathrm{NVPF}$ vs $\mathrm{Na}$ is drawn as well in Figure $7 \mathrm{c}$ (dashed line). It clearly shows that the two plateaus of NVPF are complete for the full cell since the voltage drop around $3.7 \mathrm{~V}$ is observed at half of the discharge capacity. As the cathode is fully discharged, the irreversible capacity of $29 \mathrm{~mA} \mathrm{~h} \mathrm{~g}^{-1}\left(\mathrm{Na}_{3+x} \mathrm{VPF}\right)$ corresponds to $\mathrm{Na}_{\text {reservoir }}$, i.e. the capacity provided by the extra $x$, which in this case must equal to 0.45 .

Turning to the energy density gains provided by the Na reservoir approach we plotted in Fig. 8 the specific energy of the simulated $\mathrm{NVPF} /$ hard $\mathrm{C}+$ additive discharge profiles as a function of the added capacity using compounds having specific capacities of 200 (red), 300 (green), 600 (blue) and $1165 \mathrm{~mA} \mathrm{~h} \mathrm{~g}^{-1}$ (black curve). For the lowest amounts of additive, a quasi linear specific energy increase 

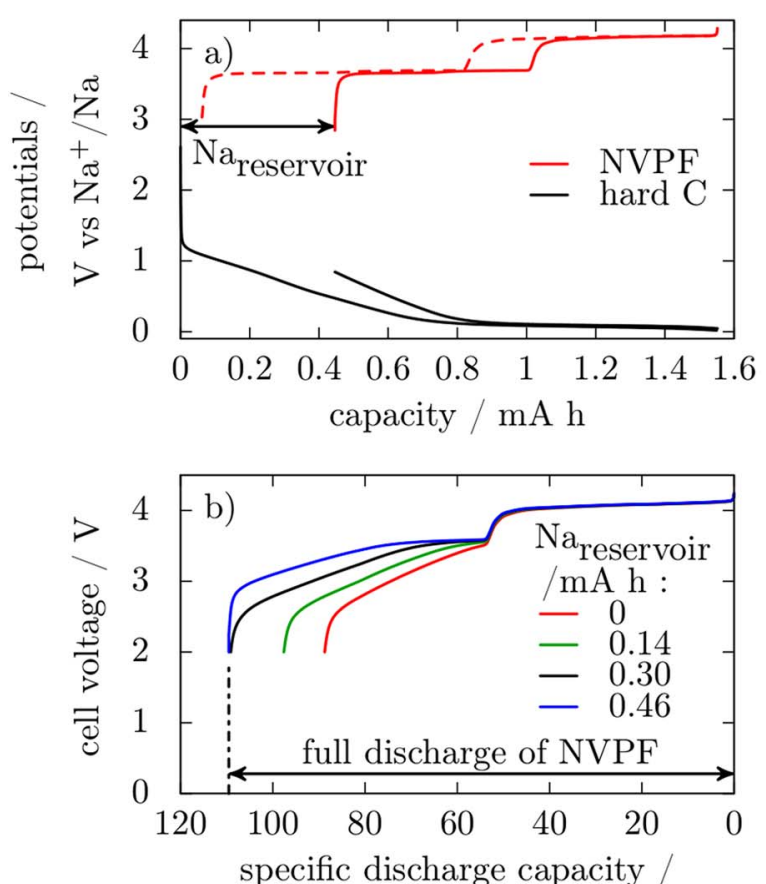

$\mathrm{mA} \mathrm{h} \mathrm{g}^{-1}(\mathrm{NVPF})$

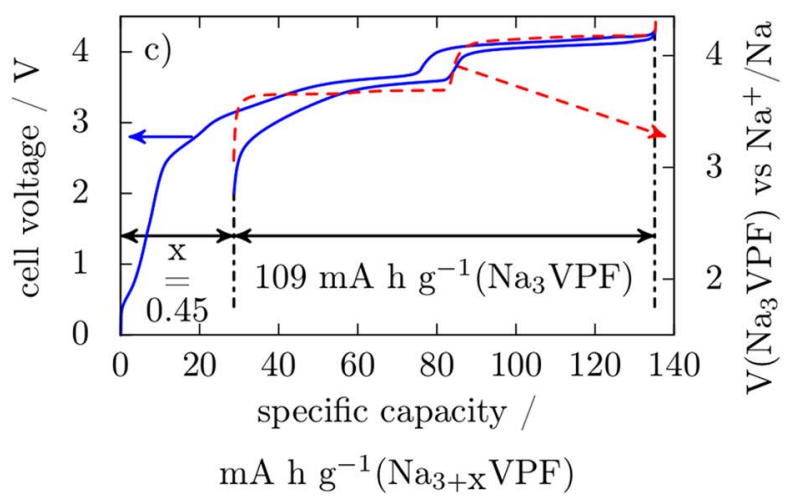

Figure 7. a) Method for the simulation of the discharge profile of NVPF / hard $\mathrm{C}$ full cells when a sodium reservoir additive is included to compensate for the irreversible capacity of the cell; b) discharge profiles of NVPF / hard $\mathrm{C}$ cells with reservoir capacities of $0,0.14,0.3$ and $0.46 \mathrm{~mA} \mathrm{~h}$ and a $5 \mathrm{mg}$ anode; c) first cycle of an experimental $\mathrm{Na}_{3.45} \mathrm{VPF} /$ hard $\mathrm{C}$ cell at $\mathrm{C} / 10$ in $\mathrm{EC}_{50} \mathrm{DMC}_{50}-1 \mathrm{M} \mathrm{NaPF}_{6}$.

is observed. When pure Na metal is used as additive $\left(1165 \mathrm{~mA} \mathrm{~h} \mathrm{~g}^{-1}\right)$, a maximum of $267 \mathrm{~W} \mathrm{~h} \mathrm{~kg}^{-1}$ is obtained, which represents a $13 \%$ increase with respect to the NVPF / hard C cell without additive. Such a maximum is reached when the capacity of the additive is around $0.3 \mathrm{~mA} \mathrm{~h}$, which corresponds to the irreversible capacity of hard $\mathrm{C}+\mathrm{NVPF}$ in the cell, $\mathrm{C}_{\text {irr }}$. Further increasing the amount of additive does not bring any benefits. Using $\mathrm{Na}_{3} \mathrm{P}$ instead of $\mathrm{Na}$ $\left(\sim 600 \mathrm{~mA} \mathrm{~h} \mathrm{~g}^{-1}\right.$ practical capacity $\left.{ }^{9,15,16}\right)$, the maximum is $263 \mathrm{~W} \mathrm{~h} \mathrm{~kg}^{-1}$ of active material. With additives at 300 or $200 \mathrm{~mA} \mathrm{~h}$ $\mathrm{g}^{-1}$, it decreases to 256 and $249 \mathrm{~W} \mathrm{~h} \mathrm{~kg}^{-1}$, respectively, which still correspond to improvements of 8 and $5 \%$ as compared to the cell without $\mathrm{Na}$ reservoir additive. Equivalent curves were obtained by using the maximum at $4.2 \mathrm{~V}$ in Figure 6 as a starting point for the simulations.

To experimentally validate these results, $\mathrm{Na}_{3+x} \mathrm{VPF} /$ hard $\mathrm{C}$ cells were assembled for different values of $x$. The mass of $\mathrm{Na}_{3+x} \mathrm{VPF}$ was adjusted so that the first charge capacity of these cells is in the range of 300 to $310 \mathrm{~mA} \mathrm{~h} \mathrm{~g}^{-1}$ (hard C). The energy of these cells is plotted in Figure 8 for the first discharge, from 4.3 to $2 \mathrm{~V}$ at $\mathrm{C} / 10$. This

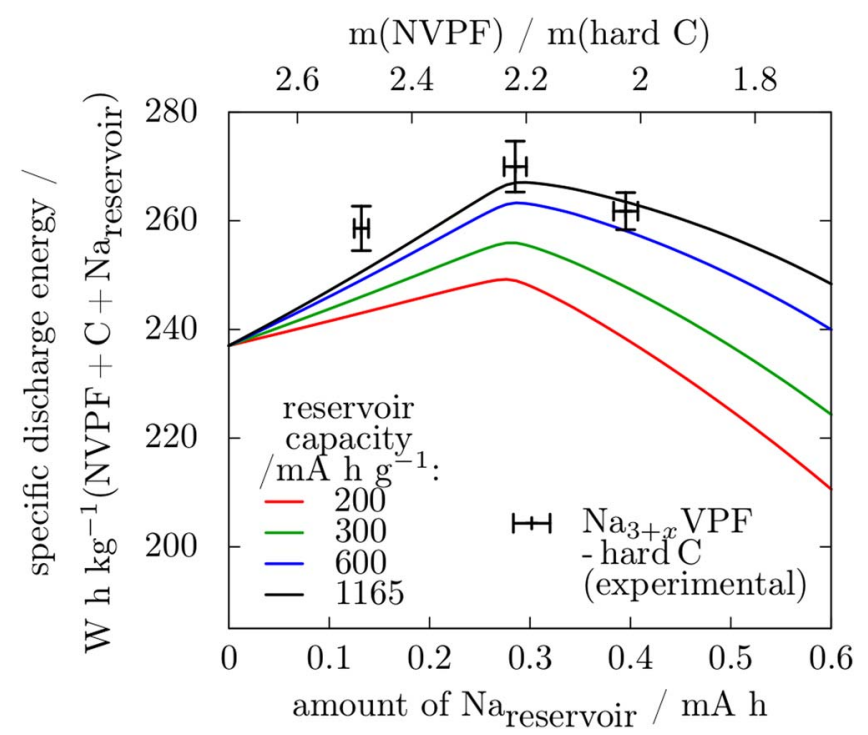

Figure 8. Specific energy of simulated full cells (lines) as a function of the capacity provided by the sodium reservoir additive for different values of the specific capacity of the additive. The mass of hard $\mathrm{C}$ and first charge capacity are constant to $5 \mathrm{mg}$ and $1.55 \mathrm{~mA} \mathrm{~h}$, respectively. Experimental data (points) from the 1st cycle of $\mathrm{Na}_{3+x} \mathrm{VPF} /$ hard $\mathrm{C}$ cells (additive capacity $=1165 \mathrm{~mA}$ $\mathrm{h}^{-1}$ ) are reported as well.

experimental data shows a maximum $270 \pm 5 \mathrm{~W} \mathrm{~h} \mathrm{~kg}^{-1}$ energy at $\mathrm{Na}_{\text {reservoir }}=0.29 \pm 0.01 \mathrm{~mA} \mathrm{~h}$ for a $5 \mathrm{mg}$ anode, in good accordance with the simulated trend.

The NFM / hard C system.-We implemented the aforementioned simulation procedure to the optimization of NFM coin cells using either $\mathrm{P} 2-\mathrm{Na}_{2 / 3} \mathrm{Mn}_{0.5} \mathrm{Fe}_{0.5} \mathrm{O}_{2}$ or $\mathrm{P}^{\prime} 2-\mathrm{NaFe}_{0.5} \mathrm{Mn}_{0.5} \mathrm{O}_{2}$ as positive electrodes. We used the same carbon as before showing a constancy in its irreversible capacity, and assumed that both ( $\mathrm{P} 2$ and $\left.\mathrm{P}^{\prime} 2\right)$ cathodes have the same irreversible capacity as $\operatorname{NVPF}\left(5 \mathrm{~mA} \mathrm{~h} \mathrm{~g}{ }^{-1}\right)$. For sake of comparison three high cutoff voltages of $4.1,4.2$ and $4.3 \mathrm{~V}$ were investigated. The discharges were generated down to $0 \mathrm{~V}$ so as to get the maximum energy of the cells. For each of the investigated cutoff voltages, $\mathrm{R}_{\mathrm{P} / \mathrm{N}}$ was increased from 1 until the conditions at which plating occurs are reached. The resulting energy density of the simulated P2-NFM / hard C cells is plotted in Figure 9a. At 4.2 and $4.3 \mathrm{~V}$ cutoff, the specific energy increases monotonously with $\mathrm{R}_{\mathrm{P} / \mathrm{N}}$. It reaches 208 and $216 \mathrm{~W} \mathrm{~h} \mathrm{~kg}^{-1}$ at 4.2 and $4.3 \mathrm{~V}$, respectively. At $4.1 \mathrm{~V}$, a maximum of $189 \mathrm{~W} \mathrm{~h} \mathrm{~kg}^{-1}$ is obtained for $\mathrm{R}_{\mathrm{P} / \mathrm{N}}=2.5$. Above this value, the energy is nearly constant: it decreases by $1.7 \%$ until plating occurs.

The impact of $\mathrm{Na}$ reservoir was also estimated in the case of the $\mathrm{P} 2-\mathrm{NFM}$ / hard C system, using the same procedure as described in Figure 7. In absence of Na reservoir, a practical optimum performance of $211 \mathrm{~W} \mathrm{~h} \mathrm{~kg}^{-1}$ is simulated for $\mathrm{R}_{\mathrm{P} / \mathrm{N}}=2.3$ and a cutoff voltage of $4.3 \mathrm{~V}(*$ Fig. 9a). The energy obtained with sodium reservoir additives is plotted in Figure $9 \mathrm{~b}$ for increasing reservoir capacity and specific capacities of the $\mathrm{Na}$ reservoir additive of 400,600 and $1165 \mathrm{~mA} \mathrm{~h} \mathrm{~g}^{-1}$. Starting from P2-NFM at $x=2 / 3$, using $\mathrm{Na}$ as reservoir $\left(1165 \mathrm{~mA} \mathrm{~h} \mathrm{~g}^{-1}\right)$ is equivalent to a cathode having a higher value of $x$. At $0.43 \mathrm{~mA} \mathrm{~h}$ provided by $\mathrm{Na}$, the configuration is equivalent to the $\mathrm{P}^{\prime} 2$ / hard $\mathrm{C}$ system $(x=1)$ and $233 \mathrm{~W} \mathrm{~h} \mathrm{~kg}^{-1}$ are obtained. This value was confirmed experimentally using $\mathrm{P}^{\prime} 2-\mathrm{NFM}$ as cathode material, leading to $234 \mathrm{~W} \mathrm{~h} \mathrm{~kg}^{-1}$ energy at first discharge. Further increasing the amount of $\mathrm{Na}$ as reservoir additive allows compensating for the irreversible capacity of the electrodes with the feasibility to reach an optimum capacity of $246 \mathrm{~W} \mathrm{~h} \mathrm{~kg}^{-1}$. By adding materials having capacities of 400 and $600 \mathrm{~mA} \mathrm{~h} \mathrm{~g}^{-1}$, separately, maximum energy densities of 225 and $225 \mathrm{~W} \mathrm{~h} \mathrm{~kg}^{-1}$, respectively, are achievable. $\mathrm{Na}$ is of course the most efficient additive, but unlike the case of 

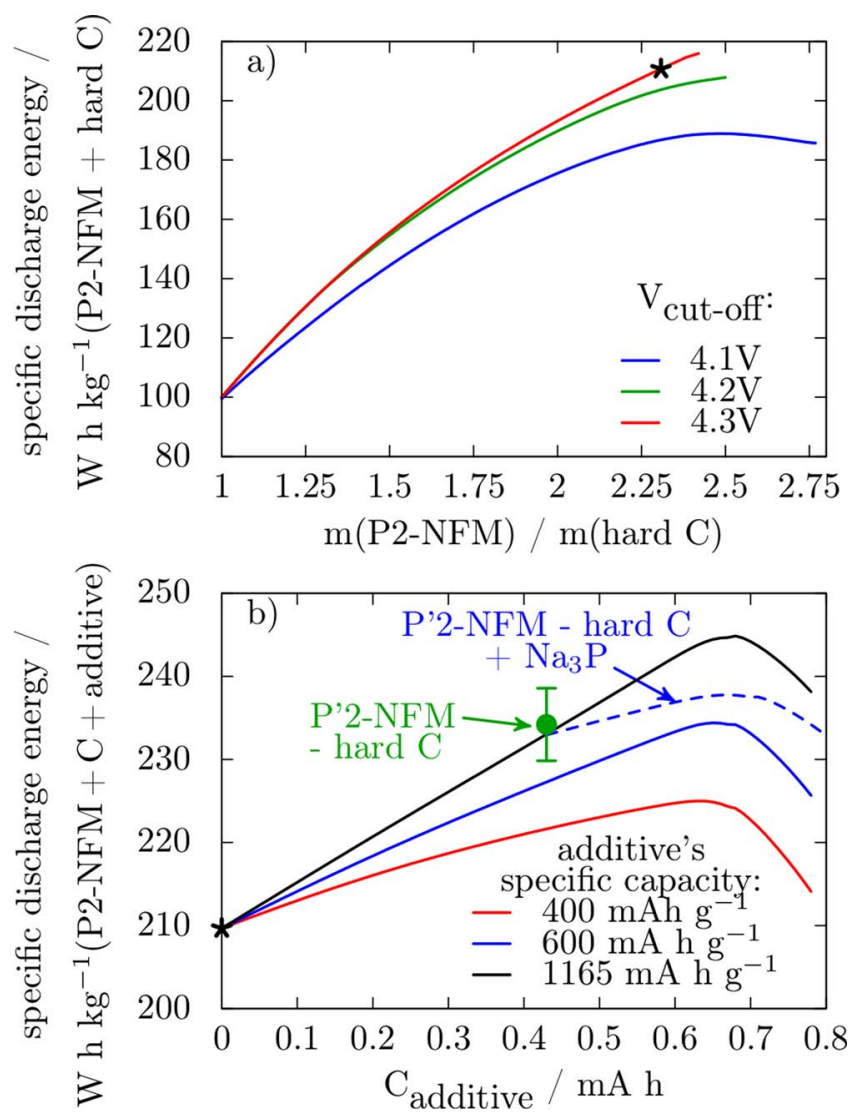

Figure 9. a) Simulated specific energy of the P2-NFM / hard C system as a function of the cathode to anode mass ratio for higher cutoff voltages of 4.1 , 4.2 and $4.3 \mathrm{~V}$ and discharge down to $0 \mathrm{~V}$; b) specific energy obtained using $\mathrm{Na}$ reservoir additives with $\mathrm{P} 2$-NFM / hard C(solid lines) and $\mathrm{P}^{\prime} 2$ / hard C (dashed line). The experimental specific energy of a $\mathrm{P}^{\prime} 2 /$ hard $\mathrm{C}$ cell is also plotted in (b).

NVPF no extra sodium can be inserted in the fully sodiated $\mathrm{P}^{\prime} 2-\mathrm{NFM}$ phase. In practice, the most efficient solution is to use this $\mathrm{P}^{\prime} 2-\mathrm{NFM}$ phase in combination with $\mathrm{Na}_{3} \mathrm{P}\left(600 \mathrm{~mA} \mathrm{~h} \mathrm{~g}^{-1}\right)$ to compensate for the electrodes' irreversible capacity. This case was simulated leading to the dashed blue curve in Fig. $9 \mathrm{~b}$ which cumulates $238 \mathrm{~W} \mathrm{~h} \mathrm{~kg}^{-1}$. This small increase in energy density $(2 \%)$ provided by the addition of $\mathrm{Na}_{3} \mathrm{P}$ can simply be explained bearing in mind that most of the capacity is recovered at low potential.

For comparative purposes, based on the optimum $\mathrm{R}_{\mathrm{P} / \mathrm{N}}$ values deduced from simulations, full NVPF / hard $\mathrm{C}, \mathrm{Na}_{3.45} \mathrm{VPF} /$ hard $\mathrm{C}$ and $\mathrm{P}^{\prime}$ 2-NFM / hard C Na-ion coin cells with $\mathrm{R}_{\mathrm{P} / \mathrm{N}}$ ratios of 2.65, 2.1 and 1.65 , respectively, were assembled and evaluated for energy density, cycling and power rate comparisons. For meaningful comparisons, the operating voltage window of the cells was adjusted depending on the cathode material to ensure that the anode is fully desodiated in all cases (as in Figure 3). The cycling curve for $\mathrm{P}^{\prime} 2-\mathrm{NFM} /$ hard $\mathrm{C}$ cell shows a $10 \%$ decrease in energy density over the fourth cycle that is followed by a lower decay rate $(13 \%)$ for the subsequent 50 cycles. This contrasts with the behavior of NVPF-based cells which show a similar initial energy density $\left(235 \mathrm{~W} \mathrm{~h} \mathrm{~kg}^{-1}\right)$ but with a lower energy density decay (8\%) and no sharp initial drop. For sake of completeness we experimented that NVPF / hard C-based cells with a $\mathrm{R}_{\mathrm{P} / \mathrm{N}}$ of 2.9 and a cutoff voltage of $4.2 \mathrm{~V}$ (not plotted in Figure 10a) shows the same initial energy density but with better stability upon cycling (4\% decay after 50 cycles). Lastly, the cell using $\mathrm{Na}_{3.45} \mathrm{VPF}-$ based electrode shows a higher density $\left(265 \mathrm{~W} \mathrm{~h} \mathrm{~kg}^{-1}\right)$ due to the beneficial aspect of the Na reservoir, which decays by $9 \%$ over 50 cycles. We also compared the cells in terms of energetic efficiency, i.e., ratio of
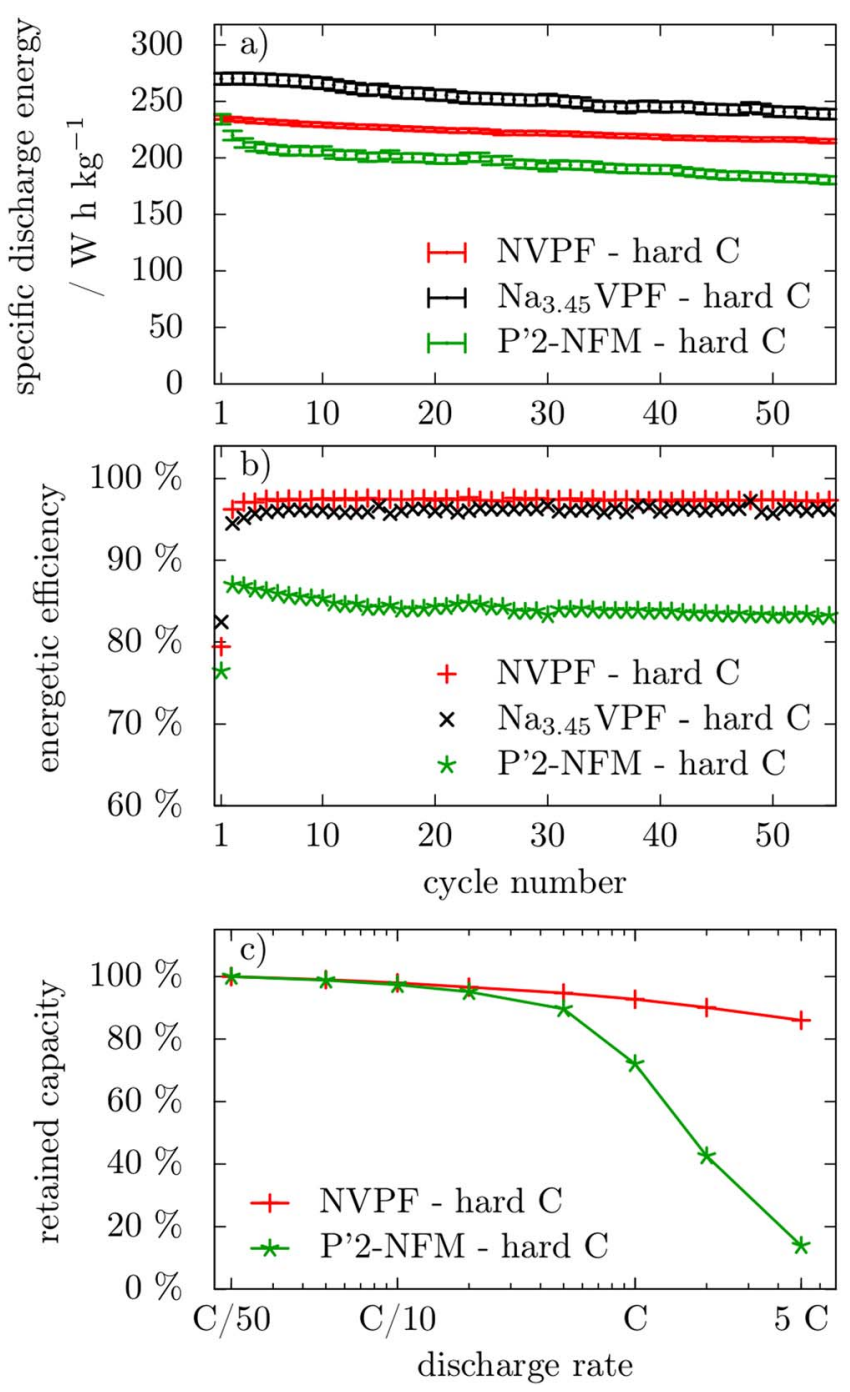

Figure 10. Discharge energy (a) and energetic efficiency (b) measured during galvanostating cycling of $\mathrm{Na}_{3} \mathrm{VPF} / \mathrm{hard} \mathrm{C}, \mathrm{Na}_{3.45} \mathrm{VPF} / \mathrm{hard} \mathrm{C}$ and $\mathrm{P}^{\prime} 2-\mathrm{NFM} /$ hard C cells with $4.3 \mathrm{~V}$ higher cutoff voltage; c) signature curve of NVPF / hard $\mathrm{C}$ and NFM / hard C cells measured after 4 galvanostatic cycles.

the energy recovered in discharge vs. the energy spent on charge. We found a drastic improvement (from $\sim 88 \%$ to $~ 96 \%$ ) in going from $\mathrm{P}^{\prime}$ 2-NFM to NVPF or $\mathrm{Na}_{3.45} \mathrm{VPF}$-based cells while the three types of cells show $99 \%$ coulombic efficiency after the first four cycles. Such a difference is due to the important voltage hysteresis between charge and discharge, as seen in Figure 2 for the layered compounds that numerous groups try to combat via $\mathrm{Mg}_{-}{ }^{17}$ or $\mathrm{Ni}^{-18}$ substitution. Lastly, the polyanionic and layered oxides-based systems were compared in terms of power rates using signature curves. NVPF / hard C cells can deliver $85 \%$ of their initial capacity at $5 \mathrm{C}$ while at the same rate NFM-hard C solely deliver $15 \%$. Such a high rate capability of NVPF / C Na-ion cells confirms previous reports. ${ }^{6}$

Finally, Figure 11 recaps on a histogram the maximum specific energy (colored bars) and energy density (striped bars) that can be obtained for the different systems: NFM / hard C and NVPF / hard C with or without sodium reservoir additives. P2-NFM gives the lowest specific energy because less than $2 / 3$ of the $\mathrm{Na}^{+}$storage capability of the material can be used. Using the fully sodiated $\mathrm{P}^{\prime} 2$ phase, the same energy as with NVPF is obtained, $235-237 \mathrm{~W} \mathrm{~h} \mathrm{~kg}^{-1}$. Adding $\mathrm{Na}_{3} \mathrm{P}$ to counterbalance the irreversible capacity of the $\mathrm{P}^{\prime} 2-\mathrm{NFM}$ and hard $\mathrm{C}$ brings a little $2 \%$ energy increase. The most performing configuration in terms of specific energy is the use of sodium to counterbalance 


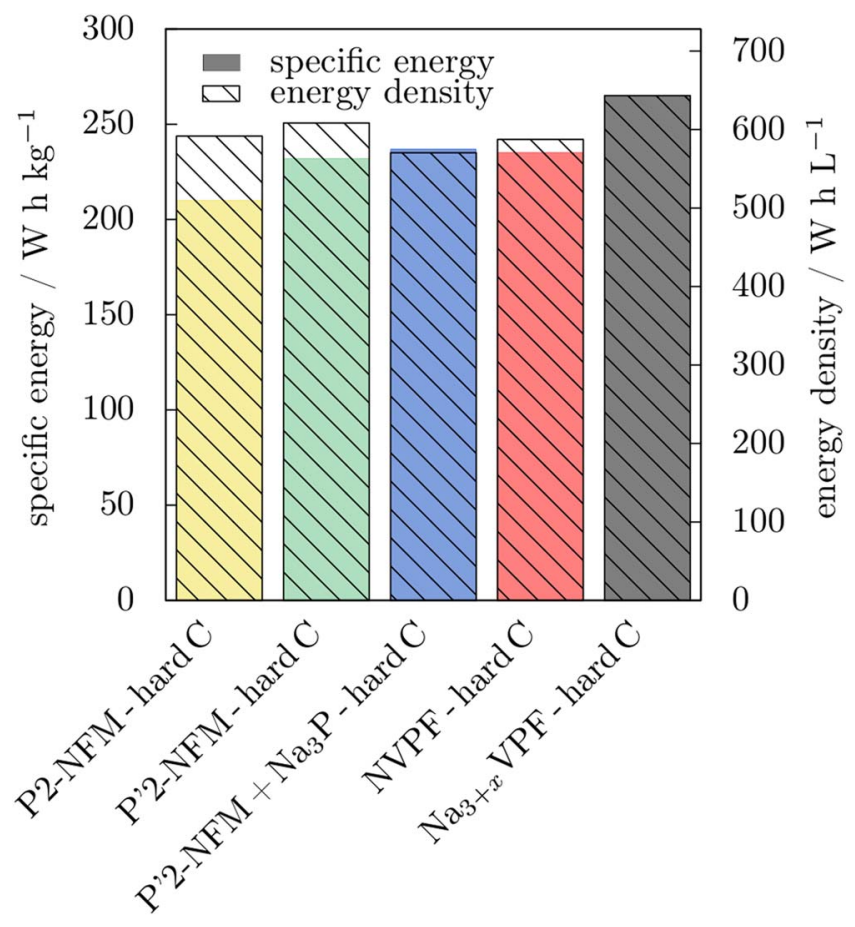

Figure 11. Maximum specific energy (color bars) and energy density (striped bars) attainable with the different configurations, reported to the total mass and volume, respectively, of anode and cathode active material.

the irreversible capacity in the NVPF-hard C system, for instance by means of a composite containing appropriate proportions of the end members $\mathrm{Na}_{3} \mathrm{VPF}$ and $\mathrm{Na}_{4} \mathrm{VPF}$ phases. With this cathode material, up to $267 \mathrm{~W} \mathrm{~h} \mathrm{~kg}^{-1}$ can be reached.

Volumetric energy densities were calculated using the theoretical densities of NVPF, NFM and $\mathrm{Na}_{3} \mathrm{P}\left(3.2,4.2\right.$ and $1.8 \mathrm{~g} \mathrm{~cm}^{-3}$, respectively) and a value of $1.6 \mathrm{~g} \mathrm{~cm}^{-3}$ for the carbon anode. The most energetic system per volume unit remains $\mathrm{Na}_{3+\mathrm{x}} \mathrm{VPF} /$ hard $\mathrm{C}$, at $643 \mathrm{~W} \mathrm{~h} \mathrm{~L}^{-1}$. Thanks to its higher density, $\mathrm{P}^{\prime} 2-\mathrm{NFM}$ brings $4 \%$ more energy density than NVPF (respectively 608 and $\left.587 \mathrm{~W} \mathrm{~h} \mathrm{~L}^{-1}\right)$. The difference between $\mathrm{P} 2-\mathrm{Na}_{2 / 3}\left(\mathrm{Fe}_{1 / 2} \mathrm{Mn}_{1 / 2}\right) \mathrm{O}_{2}$ and $\mathrm{P}^{\prime} 2-\mathrm{Na}_{1}\left(\mathrm{Fe}_{1 / 2} \mathrm{Mn}_{1 / 2}\right) \mathrm{O}_{2}$ is less significant when it comes to energy density: it is only $3 \%$ lower with the $\mathrm{P} 2$ cathode, and equivalent to the energy density of the NVPF / hard C system. However, among cathodes from the NFM family the P2 phase can still show some interest for stationary applications since it brings nearly the same volumetric energy as the fully sodiated $\mathrm{P}^{\prime} 2$, with $10 \%$ weight penalty. On the other hand, it is easier to synthesize and handle than $\mathrm{P}^{\prime} 2$ which additionally displays a lower average discharge voltage. Regarding the use of $\mathrm{Na}_{3} \mathrm{P}$ in combination with $\mathrm{P}^{\prime} 2$-NFM, the volume penalty induced by the low density of $\mathrm{Na}_{3} \mathrm{P}$ plunges the volumetric energy density performance of this configuration.

Overall this work highlights the positive attributes of the $\mathrm{Na}_{3+\mathrm{x}} \mathrm{VPF} / \mathrm{hard} \mathrm{C}$ system in terms of both volumetric and gravimetric energy when compared to the NFM / hard C system, even when reported to the total mass of both anode and cathode. This somewhat counter-intuitive result, since the capacity of P2-NFM is higher, illustrates the impact of the average potential of the cathode active material on the energy of the complete device.

\section{Conclusions}

We have reported a reliable simulation approach to estimate the voltage profile and energy density of full Na-ion cells from the experimental anode and cathode voltage curves collected vs $\mathrm{Na}^{+} / \mathrm{Na}$. Its robustness was demonstrated by comparing simulated and experimental data. We applied this predictive approach to the optimization of the $\mathrm{Na}_{3} \mathrm{~V}_{2}\left(\mathrm{PO}_{4}\right) \mathrm{F}_{3} / \mathrm{C}$ system by surveying the effect of various parameters such as the charge and discharge cutoff voltages, the ratio of positive to negative electrodes $\left(\mathrm{R}_{\mathrm{P} / \mathrm{N}}\right)$, and the addition of a Na source to the positive electrode. The model predicts an optimum energy density of $243 \mathrm{~W} \mathrm{~h} \mathrm{~kg}-1$ for $\mathrm{Na}_{3} \mathrm{~V}_{2}\left(\mathrm{PO}_{4}\right)_{2} \mathrm{~F}_{3} / \mathrm{C}$ cells having a $\left(\mathrm{R}_{\mathrm{P} / \mathrm{N}}\right)$ of 2.65 and cycled between 2 and $4.3 \mathrm{~V}$, and the feasibility to achieve $267 \mathrm{~W} \mathrm{~h} \mathrm{~kg}{ }^{-1}$ by using $\mathrm{Na}_{3.45} \mathrm{~V}_{2}\left(\mathrm{PO}_{4}\right)_{2} \mathrm{~F}_{3}$ phase as Na reservoir; these predictions were confirmed experimentally. The same approach was implemented to the optimization of the $\mathrm{Na}_{2 / 3}\left(\mathrm{Fe}_{0.5} \mathrm{Mn}_{0.5}\right) \mathrm{O}_{2} / \mathrm{C}$ system. We experimentally confirmed the predictions by assembling Na-ion cells showing an energy density of $234 \mathrm{~W} \mathrm{~h} \mathrm{~kg}^{-1}$ when $\mathrm{Na}_{1} \mathrm{Fe}_{0.5} \mathrm{Mn}_{0.5} \mathrm{O}_{2}$ is used as positive electrode. The comparative energy density performances of Na-ion cells (Fig. 11) used herein shows slightly better performances for cells based on polyanionic NVPF rather than on lamellar NFM. Such a difference will cancel out when comparing the volumetric energy density due to the lower density of NVPF as compared to NFM. This is in total contrast with the Li-ion technology for which the lamellar compounds outperform polyanionic electrode materials. This result, together with better performances of $\mathrm{NVPF}$ in terms of power rate and capacity retention as compared to NFM, indicates that Na-ion cells based on the NVPF / C chemistry presently offer the most attractive performance.

\section{Acknowledgments}

We thank i) L. Simonin and Y. Chatillon from CEA for sending us the pristine $\mathrm{Na}_{3} \mathrm{~V}_{2}\left(\mathrm{PO}_{4}\right)_{2} \mathrm{~F}_{3}$ materials that we have been using for the present study and ii) members the RS2E Na-ion task force (C. Masquelier, L. Croguennec) for helpful discussions.

\section{References}

1. H. Vikström, S. Davidsson, and M. Höök, Appl. Energ., 110, 252 (2013).

2. D. Larcher and J-M. Tarascon, Nat Chem, 7, 19 (2015).

3. A. Ponrouch, D. Monti, A. Boschin, B. Steen, P. Johansson, and M. R. Palacín, J. Mater. Chem. A, 3, 22 (2015).

4. S. Komaba, T. Ishikawa, N. Yabuuchi, W. Murata, A. Ito, and Y. Ohsawa, ACS Appl. Mater. Interfaces, 3, 4165 (2011).

5. M. Moshkovich, Y. Gofer, and D. Aurbach, J. Electrochem. Soc., 148, E155 (2001).

6. A. Ponrouch, R. Dedryvère, D. Monti, A. E. Demet, J. M. Ateba Mba, L. Croguennec, C. Masquelier, P. Johansson, and M. R. Palacín, Energy Environ. Sci., 6, 2361 (2013).

7. Y.-U. Park, D.-H. Seo, H. Kim, J. Kim, S. Lee, B. Kim, and K. Kang, Adv. Funct. Mater, 24, 4603 (2014)

8. N. Yabuuchi, M. Kajiyama, J. Iwatate, H. Nishikawa, S. Hitomi, R. Okuyama, R. Usui, Y. Yamada, and S. Komaba, Nat. Mater., 11, 512 (2012).

9. B. Zhang, R. Dugas, G. Rousse, P. Rozier, A. M. Abakumov, and J. M. Tarascon, Nat. Commun., 6, 10308 (2016).

10. M. Doyle, J. Newman, and J. Reimers, J. Power Sources, 52, 211 (1994).

11. A. Rudola, D. Aurbach, and P. Balaya, Electrochem. Commun., 46, 56 (2014).

12. D. I. Iermakova, R. Dugas, M. R. Palacín, and A. Ponrouch, J. Electrochem. Soc., 162, A7060 (2015).

13. B. Zhang, C. Ghimbeu, C. Laberty, C. Vix-Guterl, and J.-M. Tarascon, Adv. Energy Mater, in press.

14. Z. Chen, Y. Qin, and K. Amine, Electrochim. Acta, 54, 5605 (2009).

15. Y. Kim, Y. Park, A. Choi, N.-S. Choi, J. Kim, J. Lee, J. H. Ryu, S. M. Oh, and K. T. Lee, Adv. Mater, 25, 3045 (2013).

16. J. Qian, X. Wu, Y. Cao, X. Ai, and H. Yang, Angew. Chem. Int. Ed., 52, 4633 (2013).

17. J. Billaud, G. Singh, A. R. Armstrong, E. Gonzalo, V. Roddatis, M. Armand, T. Rojo, and P. G. Bruce, Energy Environ. Sci., 7, 1387 (2014).

18. E. Talaie, V. Duffort, H. L. Smith, B. Fultz, and L. F. Nazar, Energy Environ. Sci., 8, 2512 (2015). 